\title{
Participatory Governance and Institutional Innovation - A Case of Andhra Pradesh Forestry Project (JFM)
}

\author{
M. Gopinath Reddy* \\ *Madhuusudana Bandhii**
}

\section{Introduction}

Forests are among the most crucial links in the ecosystem and environment sustainability. In addition to the direct use values, forests resources protect the environment in different ways like watershed protection, nutrient cycling, pollution control, micro-climatic regulation, carbon sequestration, etc. Depletion and degradation of forest resources lead to serious environmental consequences not only at the local and regional level but also at global level. In fact, the consequences of degradation are increasingly felt in terms of declining productivities of inter linked natural resources such as land, water, grass lands, etc. Though the impacts, in terms of loss of production, are not realised at the macro level, the problem is of very serious concern at the regional level. Unless effective measures are adopted to arrest degradation, achieving sustainable development would remain a distant dream.

\section{Forest Policies During Colonial and Post - Colonial Period}

The first Indian Forest Act was drafted in 1865. Under this act, the Forest resources were brought under the control of State. Of course this was done by the colonial administration to meet its future imperial needs. Later a Reserved Forest Act 1878 came into operation in most of the British province in India. For the first time through this act, the Forests were classified as 'Reserved' and 'Protected' and paved for some sort of conservation, though again with vested interests to serve the purpose of the Imperial Administration. Under this act, the Forest Department (FD) took over forest under its control restricting the rights of the tribals and forest users from their traditional customary rights in the guise of reserving forests.

\footnotetext{
*Associate Professor, Centre for Economic and Social Studies (CESS), Nizamiah Observatory Campus, Begumpet, Hyderabad (India)

${ }^{* *}$ Research Associate, CESS, Hyderabad (India)
} 
The efforts to recognise forestry as land use distinctly different from agriculture and earmarking for such land used, made through the first forest policy of 1894. This policy's major objective of Timber production had nothing for the local people since the policy provided only for State ownership and regulation.

The early post-colonial Government forest policies were not different from the colonial one. There have been various committees formed between 1950 and 1977 but most of them were mere cosmetic in nature than substantive. The National Forest Policy of 1952 also had not considered the needs of local people. In fact, its aim was to supply timber for the industrial needs. In the other words, the commercialisation of forest was emphasised like the colonial region at the cost of the local people.

Same policy was followed until the National Commission on Agriculture 1976, which tried to make an alternative arrangement of supplying timber to the industries through Social Forestry (SF) (introduced to reduce the local population pressure on the forest). Still retaining the emphasis on commercial importance of forestry alleging that rural communities as the main culprits of its destruction. But SF could not take off and led to the conflicts between local communities and FD triggering the process of further degradation of forest and at the same time affecting the livelihoods of forest dwellers and its dependants adversely.

The two other forests related acts in post independence era were the Wild Life Protection Act (WLPA), 1972 and the Forest Conservation Act (FCA), 1980, though the operative law had still remained Indian Forest Act, 1927 which was consolidated on the Act of 1878.

The policy of 1988 is considered as a watershed in the history of Indian forest policy since it envisaged for preservation and restoration of ecological balance, conservation of the natural heritage of the country by preserving the remaining natural forests and protecting the vast genetic resources for the prosperity, fulfilling the basic requirement of the rural and tribal peoples residing near the forest and also maintenance of the intrinsic relationship between forest and the tribals and other people living in and around the forest by protecting their customary rights and concessions on the forest. Since the earlier policies of ignoring the forest dependents had led to 
many conflicts and unrest leading to ineffective control of the deforestation by the FD. Now the forced policy change saw the FD incorporating the people in the forest management. In the other words shift from the commercial forest policy to people oriented forest policy leading to the introduction of Joint Forest Management (JFM). Based on the Union Government direction, different State Governments in India decided to implement the JFM since the early 90s. 27 States to date have passed the resolution to implement the JFM (See Table - 1). Andhra Pradesh (AP) started implementing JFM since in 1992.

Table - 1 : Number of JFM committees and area of JFM in different States in India as on 1-3-2002

\begin{tabular}{|r|l|r|r|}
\hline SI.No. & \multicolumn{1}{|c|}{ Name of the State } & Area under JFM (Sq.kms) & \multicolumn{1}{|c|}{ No. of VSS / FPCs } \\
\hline 1 & Andhra Pradesh & 17675.70 & 6816 \\
\hline 2 & Arunachal Pradesh & 58.10 & 13 \\
\hline 3 & Assam & 69.70 & 245 \\
\hline 4 & Bihar & 741.40 & 296 \\
\hline 5 & Chhattisgarh & 28382.55 & 6412 \\
\hline 6 & Goa & 130.00 & 26 \\
\hline 7 & Gujarat & 1380.15 & 1237 \\
\hline 8 & Haryana & 658.52 & 471 \\
\hline 9 & Himachal Pradesh & 1112.47 & 914 \\
\hline 10 & Jammu \& Kashmir & 795.46 & 1895 \\
\hline 11 & Jharkhand & 4304.63 & 1379 \\
\hline 12 & Karnataka & 1850.00 & 2620 \\
\hline 13 & Kerala & 49.95 & 32 \\
\hline 14 & Madhya Pradesh & 43000.00 & 10443 \\
\hline 15 & Maharashtra & 6866.88 & 2153 \\
\hline 16 & Manipur & 5072.92 & 82 \\
\hline 17 & Mizoram & 127.00 & 129 \\
\hline 18 & Nagaland & 1500.00 & 55 \\
\hline 19 & Orissa & 7834.67 & 12317 \\
\hline 20 & Punjab & 735.60 & 184 \\
\hline 21 & Rajasthan & 3093.36 & 3042 \\
\hline 22 & Sikkim & 6.00 & 158 \\
\hline 23 & Tamil Nadu & 3733.89 & 999 \\
\hline 24 & Tripura & 319.89 & 180 \\
\hline 25 & Uttar Pradesh & 507.03 & 540 \\
\hline 26 & Uttaranchal & 6066.08 & 7435 \\
\hline 27 & West Bengal & 4880.95 & 3545 \\
\hline $\mathbf{2 7}$ & Total & $\mathbf{1 4 0 , 9 5 3 . 6 0}$ & $\mathbf{6 3 , 6 1 8}$ \\
\hline
\end{tabular}

Source: RUPFOR (2002)

\section{Forest Policies in AP - Pre and Post Independence}

By the time the State of AP was formed on $1^{\text {st }}$ November 1956, the parts of the present State were under the domain of British and Nizams. Hence the two different forest acts were in practice in their respective regions. Madras Forest Act of 1882 governed the Coastal and 
Rayalaseema districts of Srikakulam, Vishakahapatnam, Kakinada, Eluru, Machilipatnam, Ongole, Godavar, Krishna, Anantapur, Kurnool, Cuddapah, Nellore, Chittoor and Guntur, while the Telangana districts of Adilabad, Karimnagar, Medak, Khammam, Nalagonda, Nizamabad, Mahbubnagar and Warangal were governed by Hyderabad Forest Act 1915.

The unique feature of Telangana was that forest resources in the region till $19^{\text {th }}$ century were not managed separately; instead it was under the control of the Revenue Department. Though in 1857 a separate department for forests was established but for controlling only 13 species. From time to time the forest acts were made but only to consolidate on revenue aspect. Until the revision of 1916 Forest Act over the earlier one of 1900, which had laid the foundation for the establishment of real Forest Administration. It was also repealed by Hyderabad Forest Act of 1945, which was modelled on the lines of Indian Forest Act (Gogia, 2002). On the tribal front, the Nizams rule was unfortunate for them since they were always at the receiving end for the denial of their customary rights.

The post independence saw Law Commission being set up to integrate the two Forest Acts existing in the respective regions of Madras Province and Nizams. The result was the Andhra Pradesh Forest Act, 1967 that was drafted and passed by the legislature and it is in force from April 1967 (Gogia, 2002; Sunder et.al, 2001). It was followed by various legislations like Forest Offence Rules of 1969, Andhra Pradesh Forest Produce Transit Rules of 1970, Andhra Pradesh Minor Forest Produce (Regulation of Trade) Act of 1971 and lately Andhra Pradesh Scheduled Areas Minor Forest Produce (MFP) (Regulation of Trade) Regulation of 1979 were legislated to combat the situations of forest offences, trade control over forest produce etc.

\section{Conflicts and Tribal Uprisings in AP}

By close of 1832, disturbances in the Zamindari of Kasipuram, Payakaraopet and Palakonda of the present day Srikakulam district resulted in passing of Act XXIV of 1839 wherein the collector was vested with extraordinary powers, Even after the implementation of this Act troubles broke out in many other areas continuing into $20^{\text {th }}$ century. The disturbances, which started by close of 1832 in the Srikakulam district with the passing of Act XXIV of 1839 continued into $20^{\text {th }}$ century, which saw Rampa Rebellion in Godavari district when tribals were 
barred from entering into forests. Alluri Sitaram Raju led the uprising during 1922-24 when the tribals were forced to lay the roads with free labour. Gond Revolt of 1940 in Adilabad district started because of the influx of outsiders and land alienation following the new forest conservancy laws. In the post-independence period Naxalite ${ }^{11}$ movement erupted mainly initially in the Srikakulam district during 1968-70 due to exploitation by the Sahukars (Rich Locals or Money Lenders) (Rao and Rao, 1982; Arnold, 1982).

The battles on behalf of the forest dwellers have not only been fought in the press on an intellectual platform, but have actually been carried out in the countryside. There have been both armed struggles and political movements by tribals to regain control over what they perceived to be their lands. Several heavily forested districts in AP, Maharashtra and Madhya Pradesh have witnessed armed rebellion by the so-called Naxalite Movement directed against the State (Saxena, 2000). In AP the Telangana region was affected by the political decision in 1977, notifying lambadas (tribe) as ST, which resulted in increased influx of lambada families from neighbouring districts of Maharashtra State that increased the pressure on forests and further loss of the indigenous Gond tribals' lands to the more aggressive lambdas.

\section{Trends of Forest Resources in AP}

In $\mathrm{AP}$, the recorded forest area is 6.38 million hectares constitutes of Reserved Forest (79.2 per cent), Protected Forest (9.4 per cent) and Unclassified Forest (1.4 per cent). The five forest types in the State include Tropical Dry Deciduous, Tropical Thorn, Tropical Moist Deciduous, Tropical Dry Evergreen and Littoral and Swamp forests. Forest area is distributed mainly in the form of a wide strip starting form Nizamabad district in the west to Srikakulam in the east. Besides, a belt runs from central to the southern part of the State in the Nallmalai hills. There are 4 National Parks spread over an area of 0.33 million ha and 21 Wildlife Sanctuaries over 1.25 million ha. Thus a total of 1.58 million ha constituting 5.76 per cent of the geographic area of the State is under protected area network. Nagarjunsagar tiger reserve, one of the 23 tiger reserves of the country, is located in the State. Kolleru bird sanctuary covering an area on 90,000 ha located in West Godavari district is an important wetland in the country.

\footnotetext{
${ }^{1}$ Naxalite is an outlawed outfit. It is also known as 'Peoples War group'.
} 
Since the late ninetenth century, large area was brought under the reserve forest in different parts of the country. Subsequently, several acts were initiated to curtail the forest-dwellers and users rights. For example, in AP, 56.62 lac hectare had been declared State forest by 1955-56 and this has increased to 61.99 lac hectares in 2001-02 (Economic Survey 2002-03). In addition to the colonial Government Forest Acts, post-colonial central Government has also enacted FCA and WLPA Acts to protect the forests. Further, the Sate Government also enacted several acts and implemented several afforestation programmes. Though according to official statistics the area of State forestland has increased over the period, the actual forest cover has not increased for the same period. Besides, the official statistics often over-estimate the area under forests and other Common Pool Resources (CPRs) and under-estimate the net sown area as the pre-existing occupation of lands under other uses, which have been declared State 'forest', and illegal encroachments are not reflected in official data. The other issues related to forests like area allotted for the rehabilitated peoples due to different projects, area occupied for the different Government projects, area alienated by the different people, irrigation projects, etc., have not been reflected in the official forest statistics. These kinds of activities have increased over the period. For example, between 1950s and 1983-84, 2.07 lac hectares of forestland was lost, of which, two-third was diverted for rehabilitation and agricultural purposes. About 14 per cent of the forest area was 'encroached' by the people, the total 'loss' of forestland had increased to 2.36 lac hectares by 1991-92 (See Table - 2). As per official estimates, about 29 thousand hectares of 'encroached' forestland had been regularised till 1994. Area lost due to encroachments remained constant because only the legalised encroachments are recorded here, while the illegal encroachments far exceeds the legalised encroachments. Area lost due to rehabilitation activities between the periods is negligible, though it accounts for the second largest component of the forest area lost. It clearly indicates that the development activities and ineffectiveness of the forest officials led to the loss of forest areas in AP.

Table - 2 : Loss of Forests in AP (in hectares)

\begin{tabular}{|l|l|c|c|c|c|}
\hline $\begin{array}{l}\text { Sl. } \\
\text { No. }\end{array}$ & \multicolumn{1}{|c|}{ Purpose } & Up to 1983-84 & $\begin{array}{c}\text { \% to total area } \\
\text { lost }\end{array}$ & Up to 1991-92 & $\begin{array}{c}\text { \% to total area } \\
\text { lost }\end{array}$ \\
\hline 1. & Rehabilitation & 66759 & 32.18 & 66767 & 28.30 \\
2. & Agriculture & 87289 & 42.07 & 104902 & 44.47 \\
3. & Non-agriculture & 18816 & 09.07 & 19154 & 08.12 \\
4. & Singareni colories & 5461 & 02.63 & 15907 & 06.72 \\
5. & Encroachments & 29160 & 14.05 & 29160 & 12.36 \\
\hline
\end{tabular}




\begin{tabular}{|l|l|c|c|c|c|}
\hline 6. & Total & 207485 & 100.00 & 235889 & 100.00 \\
\hline
\end{tabular}

Source: Government of AP (GoAP), Facts and Figures 1999, FD.

Not only the forest areas were declined but also the quality of the forest (forest cover) has declined in different regions of AP. In other words, the extents of the degraded forests have been increased remarkably. According to the National Remote Sensing Agency (NRSA), about 38 percent of the forest area in AP was degraded in 1988-89. The degraded forest areas was very high when compare with the national level (24 percent) (See Table - 3). The forest degradation is not uniform in different districts of the State. In some districts, the proportion of the degradation was very low than that of the other districts. The nature and extent of degradation has reflected on the revenue generation of the forests. The degradation of forests was mainly on the ineffectiveness of the FD or non-cooperation of the people to protect the forest. To establish the co-operation between these two, the Government has initiated the JFM/ Participatory Forest Management programme. 
Table - 3 : Extent of Forest Degradation in AP

\begin{tabular}{|c|c|c|c|c|c|}
\hline \begin{tabular}{|r|} 
District \\
\end{tabular} & \multicolumn{2}{|c|}{$\begin{array}{c}\text { Total Forest Area } \\
\text { (Ha) }\end{array}$} & \multirow{2}{*}{$\begin{array}{c}\begin{array}{c}\text { Degraded Forest } \\
\text { area (ha) }\end{array} \\
39997\end{array}$} & \multirow{2}{*}{$\begin{array}{c}\begin{array}{c}\text { Degraded } \\
\% \text { Forest } \\
\text { Area }\end{array} \\
59.20\end{array}$} & \multirow{2}{*}{$\begin{array}{c}\begin{array}{c}\text { Population in } \\
\text { lacs }\end{array} \\
2,528,491 \\
\end{array}$} \\
\hline 1. Srikakulam & 69000 & $(11.9)$ & & & \\
\hline 2. Vizianagaram & 119000 & $(18.3)$ & 71319 & 76.61 & $2,245,103$ \\
\hline 3. Visakhapatnam & 441000 & $(39.4)$ & 132417 & 32.69 & $3,789,823$ \\
\hline 4. East Godavari & 323000 & $(29.9)$ & 51571 & 17.44 & $4,872,622$ \\
\hline 5. West Godavari & 82000 & $(10.5)$ & 22831 & 25.96 & $3,796,144$ \\
\hline 6. Krishna & 66000 & $(7.6)$ & 42563 & 72.57 & $4,218,416$ \\
\hline 7. Guntur & 162000 & $(14.2)$ & 136847 & 91.11 & $4,405,521$ \\
\hline 8. Prakasam & 442000 & $(25.1)$ & 85335 & 19.25 & $3,054,941$ \\
\hline 9. Nellore & 252000 & $(19.2)$ & 174606 & 71.34 & $2,659,661$ \\
\hline 10. Chittoor & 451000 & $(29.9)$ & 301197 & 66.96 & $3,735,202$ \\
\hline 11. Cuddupah & 502000 & $(32.6)$ & 141852 & 28.05 & $2,573,481$ \\
\hline 12. Kurnool & 351000 & $(19.8)$ & 89337 & 29.58 & $3,512,266$ \\
\hline 13. Anantapur & 197000 & $(10.3)$ & 129765 & 79.09 & $3,639,304$ \\
\hline 14. Mahaboobnagar & 303000 & $(16.5)$ & 68933 & 23.46 & $3,506,876$ \\
\hline 15. Ranga Reddy & 73000 & $(9.7)$ & 63071 & 87.30 & $3,506,670$ \\
\hline 16. Medak & 91000 & $(9.4)$ & 66179 & 93.84 & $2,662,296$ \\
\hline 17 Nizamabad & 181000 & $(22.6)$ & 78097 & 46.30 & $2,342,803$ \\
\hline 18 Adilabad & 723000 & $(44.9)$ & 178837 & 25.67 & $2,479,347$ \\
\hline 19 Karimnagar & 250000 & $(21.2)$ & 87465 & 38.04 & $3,477,079$ \\
\hline 20 Khammam & 843000 & $(52.7)$ & 145461 & 18.52 & $2,565,412$ \\
\hline 21 Nalgonda & 84000 & $(5.9)$ & 79689 & 95.79 & $3,238,449$ \\
\hline 22 Warangal & 371000 & $(28.8)$ & 108316 & 29.37 & $3,231,174$ \\
\hline $\mathbf{A P}$ & 6376000 & (23.2) & 2295685 & 38.02 & $75,727,541$ \\
\hline All India & 65710815 & (19.99) & 16274270 & 24.77 & $1,027,015,247^{*}$ \\
\hline
\end{tabular}

Source: NRSA (The figures in the brackets are the percentages of the district forest area of the respective districts) *Census of India 2001

\section{JFM in AP}

JFM has been implemented in the State of AP since 1992, consequent to the issuance of the first Government Order (GO). Later, this order was changed several times to incorporate pro-people measures, resulting in the GO No.173 of December 1996.

In consonance with the National Policy, the Government of AP framed State Forest Policy in 1993. Under this programme, Vana Samarakshana Samithis (VSS) or Forest Protection Committees (FPC) were established to protect the forest resources, mainly in the hill areas. The basic purpose of the VSS / FPC is to protect the forest from encroachment, grazing, theft, and 
fire, and to improve the forest in accordance with an approved JFM plan. This local plan, known as a micro plan, is formulated in stages. Through a method of 'Participatory Appraisal Method' with regard to initiation to under take the work is discussed, where all the members get a chance to air their views. After this the FD surveys the forest adjoining the village and demarcates boundaries, upholding the conclusions of the initial discussions as a framework, then the committee and the forester prepare a detailed micro plan for forest development. Thereafter, the annual programs are worked out and submitted to the FD for approval. The micro plans are premeditated to ensure the protection and restoration of the forest's productive capacity in a shortest possible time. Finally the VSS / FPC members undertake the plantation, silvicultural operations, and soil conservation works for which they are paid out of project funds. A legal memorandum of understanding between the VSS / FPC and the Forestry Department formally minutiae the duties, functions, and entitlements of everyone involved (Venkatraman and Falconer, 1998).

Since VSS / FPC is entitled to the incremental value of the produce and a right to share its income among themselves equally for protecting it, but to generate any income out of the degraded forests it takes some time, hence to motivate the members the FD address their most pressing social needs by developing and supporting the village by micro plans wherein women's thrift groups are promoted, drinking water is facilitated, water storage facilities, community halls, fishponds, household biogas plants are built and low-cost smokeless ovens, and small-scale irrigation facilities are provided to the villagers. The project supports some of these "entry point" activities, but mainly the foresters must seek the assistance of other Government departments or Non-Government Organisations (NGOs) to facilitate this broader rural development. In many instances, this experience has encouraged the Government to assign foresters the task of coordinating all rural development assistance within their localities. This trend illustrates the transformation of the Forestry Department, which now successfully integrates the conservation and development aims of the Government. The works and funds of the VSS / FPC are handled in a transparent manner jointly by the chairperson of the VSS / FPC and the Forester who acts as the secretary (Venkatraman and Falconer, 1998). This transparency helps to ensure the quality and cost-effectiveness of all activities. The role of NGOs in the VSS / FPC and Eco-development committees is that of a facilitator. Their responsibilities include bringing awareness, motivation, 
help in preparing micro-plans, help in conducting training of local communities for capacity building, leadership skills, gender sensitisation, etc.

In the beginning of the programme, VSS / FPC were entitled to 50 per cent of the 'net incremental value' of forest produce such as Non Timber Forest Produce (NTFPs), grasses and dry fuel-wood besides a 50 per cent share from the final harvest in lieu of forest protection. In 1996, the village communities were entitled 100 per cent of the 'net incremental value' of the usufructs compared to lower percentages in other States. However, the Girijan Cooperative Corporation $^{22}$ (GCC) retains monopoly rights over most NTFPs and at least $50 \%$ or as much as is required of the VSS / FPCs income must be re-invested in the JFM forest.

\section{Participatory Governance and Institutional Innovation under JFM in AP}

Participatory governance structures are envisaged and brought into practice under JFM at various levels which are discussed below (See Figure - 1)

\section{State Level JFM Committee}

The State level committee consisted of Principal Secretary of Environment Forest Science and Technology Department (EFES and T) as its chairman, Principal Secretary of Social Welfare or his nominee, Managing Director of AP Forest Development Corporation Limited, Commissioner of Tribal Welfare, Director/ Commissioner of Agriculture Department, Managing Director of Girijan Co-operative Corporation Ltd., Nominee of Secretary (Finance), Director of Women and Child Welfare, Two representatives of NGOs, a representative of Ministry of Environment and Forests (MoEF) (GOI) as the members and Principal Chief Conservator of Forests (PCCF) as member convenor. This committee was to meet quarterly to submit its report to the Government and co-ordinate among various departments of the State Government connected with the implementation of JFM concept. In order to strengthen the JFM further various Government orders were enacted in AP. These were mostly in the nature of incentives for forest protection. One such GO is regarding sharing of compounding fees to the tune of 25 per cent (agreed during the second State level committee meeting held on 26.8.1995) with the VSS / FPC members for

\footnotetext{
${ }^{2} \mathrm{GCC}$ is a government agency established to safe guard the interests of the tribals against the exploitation from the private traders and contractors with regard to selling of forest produce.
} 
better forest protection and prevention of smuggling of forest produce. The order contained directions to constitute 'three member committee' consisting of Principal Secretary of E.F.E.S and T (FOR. VI) Department, Secretary of Finance and Planning Department and PCCF of AP to scrutinise the cases apprehended by the members of VSS / FPC and recommend the award to be given to such VSS / FPC .

Fig 1: Organisational Arrangements for JFM

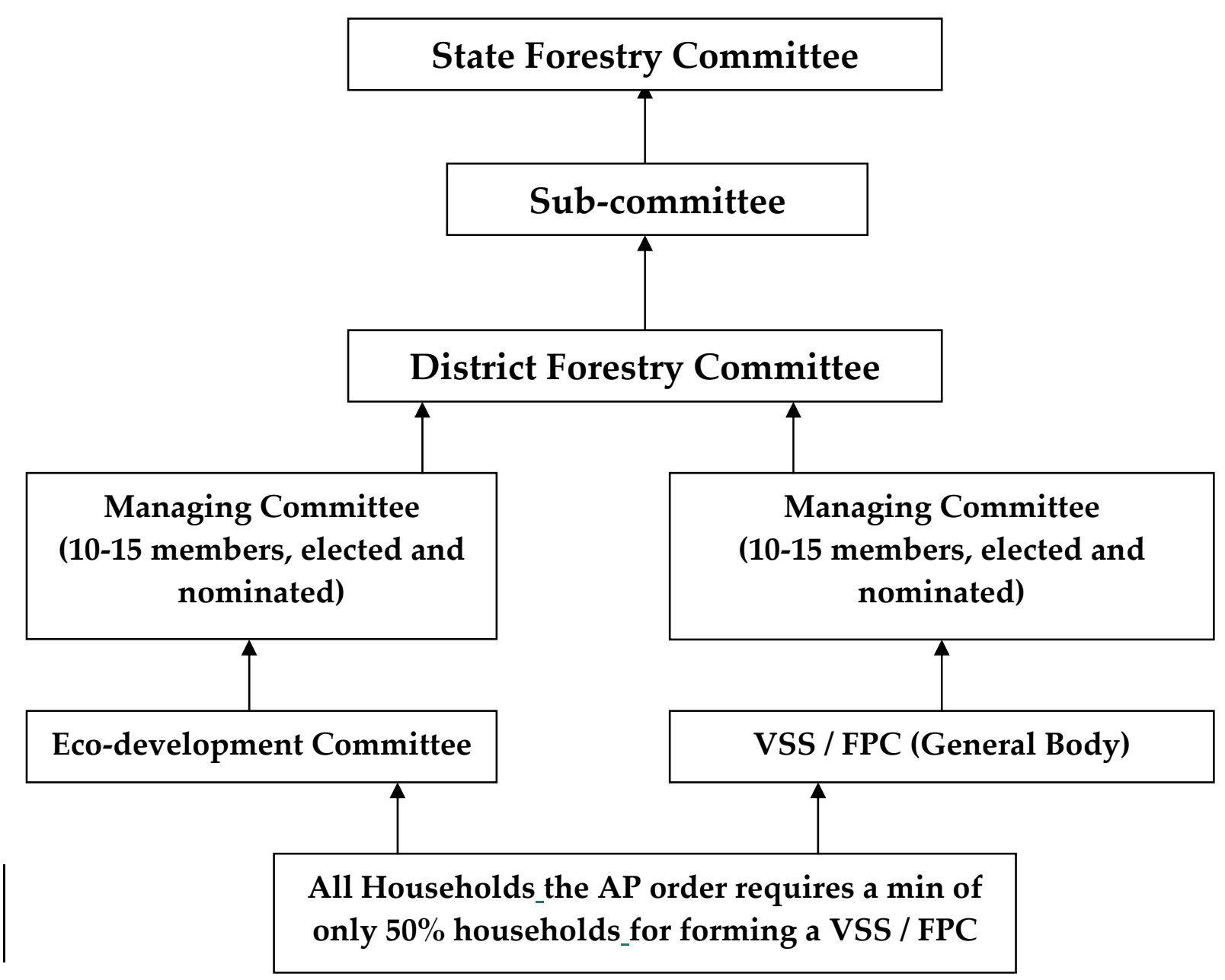




\section{District Forest Committee}

The 'District Forestry Committee' was constituted to implement JFM at the district level. The committee comprised of District Collector as its Chairman, Project Director of District Rural Development Agency, Project Officer (PO) of Integrated Tribal Development Agency (ITDA), Joint director of Agriculture, Joint Director of Animal Husbandry, Deputy Director of Social Welfare, All Territorial Divisional officers in the district, Three NGOs active in the district and Five representatives of VSS / FPC as selected by the collector respectively as the members and Divisional Forest Officer of the Headquarters of Territorial Division as Convenor Member. The function of the committee was to ensure co-ordination between the various departments of the Government at the district level involved in the implementation of the JFM and refer matters to AP State Forestry Committee as and when necessary, apart from meeting quarterly to send it's report to the PCCF and the Government regularly.

To co-ordinate and facilitate the implementation of the concept of JFM in a smooth way in the tribal areas a 'Sub-committee' was formed with PO of the ITDA as its Chairman, two NGOs to be nominated by PO of ITDA, ten members from VSS / FPC in the Agency area, again to be nominated by the PO of ITDA as members and Sub-divisional Forest Officer / Divisional Forest officer in ITDA Headquarters as member/convenor. This Sub-committee was to address themselves to the problems in carrying out the deliberations and the decisions of the AP State Forestry Committee and District Forestry Committee at the field level. The Sub-committee was also responsible to implement JFM concept within its jurisdiction and meet at regular intervals (at least quarterly) and send the report to the Conservator of Forests of the district at regular intervals. The members of the VSS / FPC, individually or jointly, were responsible to a) ensure protection of forest against encroachment, grazing, fires and thefts of forest produce, b) carry out development of forests in accordance with the approved JFM plan and improving the awareness regarding forests among rural communities. The members of the VSS / FPC had the powers to apprehend the offenders and handing them over to the authorities. The authorities have the responsibility to report back the action taken on the offenders to the VSS / FPC.

The Managing Committee (MC) was to meet at least once in a month. The MC prepares the JFM plan in coordination with the forest range officer and in consultation with all sections particularly 
women and other disadvantaged sections of the community. The JFM Plan was to be approved in the General Body (GB) of the VSS / FPC. The FD was to assist the VSS / FPC in selection / demarcation of the forest area to be covered under JFM, in preparation of micro-plan, approving the micro-plan, drawing of the budget for the plan and getting the budget approved. The FD was responsible to transfer the skills of sound silvicultural treatment and soil conservation to the members of VSS / FPC and to guide JFM micro plan implementation.

\section{Village Level Committee}

It was deliberated to bring socially homogeneous groups into the fold of each VSS / FPC. Persons from all households were eligible to become members, but those from the most disadvantaged sections of the society, the Scheduled Castes and Tribes were automatically eligible to become its member Generally, two people from each household were to become its members, and one of them had to be a woman. Most VSS / FPC ranged in size from 75 to 150 members. This GB was to elect a MC of 10 to 15 members, 33 per cent of whom were to be women, who in turn elected a Chairperson to oversee and manage the affairs of the VSS / FPC. Elected representatives were not being less than six members. The number was to increase by one for every fifty households or fraction over and above the base of 150 households. And the maximum members are restricted to ten. President of the Gram Panchayat is a member of the MC, Besides the concerned forest guard, an officer nominated by the PO Integrated Tribal Development Area, the local NGO had to be actively involved in the formation of the VSS / FPC and the Village Development Officer were also the members of the VSS / FPC. The concerned Forester / Deputy Range Officer were to be a Member Secretary of this Committee. The Forester and the Forest Guard had no voting rights. The Chairperson's term was co-terminus with MC i.e., 2 years. In the ITDA areas all the elected members had to be tribals. In the case on non-tribal areas at least $1 / 3^{\text {rd }}$ of the membership was to be reserved for Scheduled Castes (SCs) and Scheduled Tribes (STs). Non-elected members had no voting rights. On the similar lines an ecodevelopment committee was to be constituted with an elected MC. A GB meeting of the VSS / FPC had to be held once in every six months to review the action taken regarding the JFM plan and review the performance of MC. 
Although JFM was introduced in early 1990s, the growth was very slow. From a mere 133 VSS / FPC during 1994-95, it has gone up to 6726 VVS in 2001-02 in the State managing 16.89 lac hectares of forest area (See Table 4). About 7.85 lac hectares of degraded forests have been treated through these VSS / FPC. Also all the identified forest fringe villages have been covered under JFM stream. Around 13 lac people have been brought under the JFM scheme of which 6 lac are Women and nearly 5.5 lac are SCs and STs. The largest number of VSS / FPC are concentrated in Adilabad, Vishakahapatnam, Khammam districts. Krishana, Prakasham, Rangareddy and Nalgonda districts are having a low number of VSS / FPCs. The forest concentrated districts have more number of VSS / FPCs and fewer in the districts with less forests. The funds from various sources like World Bank aided AP Forestry Project, Employment Assurance Scheme (EAS) and other schemes including Centrally Sponsored Schemes were being utilized for implementation of JFM. The availability and pooling of funds, apart from State thrust on JFM explain the sudden increase in the number of VSS / FPC in the later years.

Table - 4 : Progress Of JFM Implementation in AP: 1994/95-1999/2000

\begin{tabular}{|l|c|r|}
\hline Year & $\begin{array}{c}\text { No.of VSS / FPC } \\
\text { formed }\end{array}$ & $\begin{array}{r}\text { Area Covered (in lac } \\
\text { ha) }\end{array}$ \\
\hline $1994-95$ & 133 & 0.67 \\
\hline $1995-96$ & 447 & 2.51 \\
\hline 1996.97 & 1722 & 6.44 \\
\hline $1997-98$ & 3812 & 9.28 \\
\hline $1998-99$ & 6527 & 15.46 \\
\hline $1999-00$ & 6575 & 16.52 \\
\hline $2000-01$ & 6726 & 16.82 \\
\hline $2001-02$ & 6726 & 16.89 \\
\hline
\end{tabular}

Source Economic Survey: 2000-2001, 2002-2003.

\section{The Panchayat Extension Act to Scheduled Areas (PESA), 1996}

Under the $73^{\text {rd }}$ Constitutional Amendment Act, Panchayat ${ }^{2}$ has emerged as one of the potential stakeholders in forestry $\operatorname{man}^{3}$ agement and sharing of benefits derived from it. The Panchayat is now empowered to legislate on matters (the powers and functions devolved to the Panchayats ${ }^{3}$ that specified in the Eleventh Schedule of the Indian Constitution, it is different matter that most

${ }^{3}$ Panchayats are the Local Governments. In this paper it is referred to the smallest unit of community level. 
of the States are yet to devolve the powers to the Panchayats, AP is also one such State which has not devolved all the powers to the Panchayat) relating to forestry that include land improvement, soil conservation, watershed development, SF, farm forestry, minor forest produce, fuel and fodder although management of State forest lands is not included. Extension of this Act to Schedule V areas has wider implications on forest resources in tribal areas (as specified in the V Schedule). The Gram Sabha or the Panchayat is endowed with right to ownership of NTFP. Further, the ownership to NTFP is granted to meet the bona fide requirements of local community (Pathy, nd).

The Ministry of Welfare and the Ministry of Rural Areas and Employment asked the Ministry of Environment and Forests to initiate action on the Extension Act, conferring ownership rights over MFP on Panchayats / Gram Sabhas and incorporate appropriate provisions under its own acts and rules for implementation of the decision. The latter constituted an Expert Committee under the chairmanship of C.S.Chaddha in October 1997. Gram Sabhas were Conferred the usufruct rights to improve the economic well being of the tribals but this has not been done in AP yet. Out of the net surplus available from all the MFP, at least 25 percent should be transferred back to the Gram Sabhas through the agency responsible for MFP trade. Another 25 per cent should be utilized for community development through the agency and the balance 50 percent should be given to individual collectors in proportion to the value of the produce collected by them (Pathy, nd).

\section{Impact of JFM in AP}

The following paragraphs present both positive as well as subdued impacts along with the shortcomings of the JFM programme emanating from the review of studies which evaluated JFM functioning portraying both claims and perceptions about the achievements and potentials of the JFM.

\section{Positive impact}

The swift expansion of JFM in AP has been driven by the spectacular regeneration of forests and the resulting economic gains of local people, and by the personal involvement of the State's Chief Minister, who turned the strategy into a mass movement by focussing the attention by 
ensuring access to resources from different sources to the lowest unit to make the JFM project a success (Venkatraman and Falconer, 1998). Behroonguda is one such case, where JFM was launched on May 23, 1993. It was the first VSS / FPC in AP to win official recognition. The 'village committee' comprised of 50 per cent women members in a 97-member body, was headed by a women member. In 1998, the Behroongooda also became the first VSS / FPC in A.P to obtain the fruits of forest protection. It generated income to the tune of Rs. 3,59,500 from the sale of 'teak poles'. Besides, number of non-timber forest products (NTFP) has re-emerged, which were enjoyed by the local people, on account of better protection by VSS / FPC. From the point of employment the labours were kept busy in 'coppicing shoots' for which they were paid Rs. 40-50 per day a better deal than agricultural wage. At the same time they stopped migrating for a living. In terms of income, the VSS / FPC families earned Rs. 1000 each per year apart from the 'usufruct benefits' (D'Silva and Nagnath, 2002).

Gopal and Upadhyay (2001) have also seen that after the formation of VSS / FPC in 1995 in Sugali thanda a tribal hamlet under the Muddireddipalli Panchayat of Maydukar Mandal in Cuddapah district a Participatory Rural Appraisal (PRA) exercise was undertaken in 1996 and a micro plan was prepared to address the livelihood questions. A two-pronged strategy was implemented: one was to provide the vulnerable families with improved facility to carry out agriculture and second was to provide continuous employment opportunity in the forest. In a short period of 4 years the annual average family income rose from Rs. 3,800 to 4,700. The key factors for the success was three years of continuous awareness and motivation, provision of identity cards to all the members, improved savings during JFM and improved employment and income generating activities.

The VSS / FPC in Hottebetta, a hamlet in Rolla Panchayat in Rolla Mandal in Ananatapur district, came into existence on 1996, with an initial focus on development of grasslands. Subsequently in 1996-1997 fodder development was taken up in 30 hectares of land. In the same year 5 Rock-fill Dams, 3 Check-Dams were constructed and 20,000 saplings were planted afresh, which have gone up to 61,540 by the year 1998. In other matters, the VSS / FPC resolved to develop 20 hectares into a 'Horticulture Land' with an intention of serving as source of 
independent income for sustaining the people's action, this scheme also met with significant progress (Muralidharudu et. al., 1997).

Naginayana Cheruvu, a remote area adjoining forests in the district of Ananatapur was able to see the incurring natural growth of plants to full length from 10 to 15 percent to 80 percent, resulting in substantial increase in the groundwater levels. The 'fauna' in the area too was affected with sharp increase in its population. The developments in 'Naginayana Cheruvu' indicates the positive surge in the forest growth, thanks to the policy of taking people into confidence and letting them have a say in the matters of their concern without compromising on their basic needs (Biswas et. al., 1997).

Reddy, et. al. (2000) in their study of VSS / FPC in the villages in Anantpur district have found 'natural regeneration of forests' in all but one thanda (hamlet), while the growth of plant species was relatively better than that of bushes and fodder. The reasons for such drastic change are due to control of fire, prevention of illegal felling of trees and prevention of cattle grazing. As a result, the way was paved for the growth of 'wild life'. As regards income, JFM has left a telling impact on the living conditions of the locals by generating additional income and reducing the dependence on moneylenders. The increase in economic status facilitated children's education, particularly girls, active involvement of women in VSS / FPC, etc. The seasonal migration (except one thanda) was checked and the general health improved and showed an encouraging signs towards following family planning policy by the people. This was again possible due to different works undertaken by the VSS / FPC in the area.

Due to protective measures undertaken by VSS / FPC, Juttadapalem JFM was able to develop contour trenches, plant several thousand trees and raise two hectares of fodder grass. Chandrayyapalem repaired a well for drinking water and constructed a small Check Dam to harvest rainwater. In Kannaram and Vandrujola illicit felling of trees, grazing and firewood collection was successfully contained. In Konnaram 'palm tree' fence was developed around the forest to protect it from the smugglers and cattle. The 'species' are less valuable. Among the studied areas two VSS / FPC of Kannaram and Chandrayyapalem were able to generate good employment and income in view of the fact that in these areas the commercially important 
species like tamarind, soap nut, honey, gum and beedi leaves were grown. The people here obtain firewood from the unprotected forests leading to degradation of these forests (Kameshwar et. al., 1995-96).

Mallett (2000) citing the example of Adilabad district in AP illustrates how the people who were suspicious of JFM are now eager to participate, as the fruits of JFM could be seen in the district where 45 percent of the forest was lost to agricultural encroachment between 1983 and 1993. Ever since JFM was launched this trend has been reversed, and there have been no reports of forest loss in any areas managed by the VSS / FPC. Not confining to mere forest activities the development works like community halls, check dams, drinking water structures, roads, etc, was also taken up under JFM. It also goes to show that where there is earnest participation from the people and the Government it is possible to have fruitful results (JFM - A Critique, Study). The area where JFM policy least expected to bring any sort of positive results was that of countering the 'Naxalites', which came as a 'godsend', according to the Forest Secretary and the PCCF, Adilabad, one of the strongholds of the Naxalites is today safe to visit Naxalite-infested localities because of the protection by VSS / FPC members' (Rangachari and Mukherji, 2000).

Coming to gender issues women's involvement in JFM is natural and effective due to their closeness to nature. It is felt that this 'closeness' gives them a special stake in environmental protection and conservation (Shiva, 1998). AP is one of the States, which has promoted the 'Women Self-help Group' known as 'Mahila

pu Sangam or Awal Thrift Group' on a large scale. As observed by Gopal and Upadhyay (2001) the women in Maktha Masanpalli located $75 \mathrm{Kms}$ from Hyderabad are quite active, which could be seen from the three thrift groups, which are functioning effectively.

With the formation of VSS / FPC in 1995 in Ippapenta a hamlet consisting of 35 Harijan families located in Chintakommadinne Mandal in Cuddapah district, were able to persuade the neighbouring villagers to stop their illegal activities in the forest. They were successful in convincing the rich farmers not to collect firewood and timber from the forest patch allotted to the SC colony and to restrict their cattle from grazing in the protected patch (Gopal and Upadhyay, 2001). 
According to the AP Forest Department (nd), VSS / FPC is great success in the State. Some of the important indicators of success are presented here.

- VSS / FPC members at Chengicherla in Rangareddy district got revenue of Rs. 2.26 lacs from sale of grass in the past 6 years. From the same area earlier the Government used to realise hardly Rs.5000 per annum.

- Due to generation of adequate employment in the village itself, the migration of villagers to urban areas has reduced by more than 50\% in many VSS / FPC and totally stopped in some VSS / FPC.

- The natural regeneration in forests has improved appreciably - in Kondapur VSS / FPC in the drier region of Nalgonda district, the VSS / FPC members were proud to record the revival of 26 new species in their forest due to effective protection.

- In Venkatapuram VSS / FPC of Chittoor district, 'neem' regeneration has improved so much that what was once a barren hill now looks like a 'neem' forest.

- The production of bamboo has improved under JFM. In Sonapur VSS / FPC of Adilabad district, the members have already realised about Rs.60, 000 from sale of bamboo.

- $\mathrm{A}^{4} \mathrm{P}$ boosts of the fact that as much as 24000 hectares of forest land, which was under cultivation, was reclaimed through the efforts of VSS / FPC members.

- Today the Podu ${ }^{4}$ areas in Visakhapatnam and Adilabad districts are affording more income to the people under forestry than they were under rain fed agriculture.

- Members of Belgaon and Doderna VSS / FPC of Nirmal in Adilabad district were instrumental in busting one inter-State timber smuggling racket operating from Maharashtra. They have helped in booking 5 cases with the value of seizures being around Rs. 5 lacs.

- The production of NTFP has gone up in VSS / FPC areas resulting in the villagers getting more income from collection of soap nut, seethaphal, etc.

- In Sircilla Range of Karimnagar district, members of 9 VSS / FPC could extract seethaphal worth Rs.2.67 lacs during the year 1999 from the VSS / FPC area.

\footnotetext{
${ }^{4}$ Podu is a practice of shifting cultivation by slashing the forests on the hillocks for few years and then moving on to other patch.
} 
- Members of two VSS / FPC in Chittoor district Gopalakrishnapuram and Peradam, earned about Rs.1.5 lacs from sale of tamarind grafts in the VSS / FPC area.

\section{Subdued Impact}

The JFM is not spared of failures either due to various reasons. Different studies have pointed out the subdued impact of JFM in AP. D'Silva and Nagnath (2002) pointed out that there is several ambiguity and confusions at the grass root level. The important one is about 'final harvest' and the confusion over 'incremental benefits'. As of now the villagers cannot claim on the 'old growth' (existing stock of trees). Some other studies found that disputes over forest boundary due to the ignorance of FD of the traditional village boundaries and demarcating the VSS / FPC area. In many areas the department has not thought of maintaining the balance between population and extent of forest area, but made clinical boundaries trespassing into other villages. Artificial boundaries have taken over traditional village 'polimeru' causing most of these problems. As a result in many instances the aggrieved villagers have cut down the entire plantation (R. K. Nagar VSS - Araku Mandal, Vizag district Burnt down) (JFM - A Critique, Study).

Irregularities in fund allocation are rampant with most of the VSS / FPC and EC members not knowing about it, even wastage of money on non-forestry activities like publicity material is increasing to camouflage the real intent and purpose of JFM by the 'Vested groups'. Breaching the faith the department has overlooked on the matters of 'profit sharing and compounding fees' since no VSS / FPC has received such benefits yet, leaving scope for mistrust and anger among its members (JFM - A Critique. Study).

Checking degradation from smuggling of timber is much claimed achievement of the JFM but in many places this Statement negates the reality. For instance, smuggling of timber was openly taking place in broad day light in Srikakulam district. There are claims of the NGOs having seen the timber being stacked and transported illegally in the very presence of the MRO and other revenue staff in Dommingivalasa (JFM - A Critique, Study). 
The severe repercussion of the JFM has been on the 'indigenous tribals' whose very survival and sustenance is under threat, because they are forced to do away with their traditional stay in the forest and discouraged from 'Podu' their traditional form of shifting cultivation. Although the intention of the Government to halt the 'Podu cultivation' is from the point of environment but at the same time it is the responsibility of the Government to rehabilitate and compensate them. Unfortunately in spite of resolutions available on this issue nothing concrete is coming up. Therefore the perception of the tribals in many affected areas is changing negatively towards the schemes of Government. Hence, Rao (The Hindu, nd) had posed questions to the claims of the FD that the Podu cultivators have willingly and voluntarily surrendered forestlands. He further sees the anti-poor plot by FD and the World Bank in reclamation of forestland under Podu, under the aegis of the JFM project.

Women are the predominant collectors of fodder, fuel wood and NTFPs and were supposed to benefit considerably from JFM but are, in fact, neglected in most of the areas. As Sarin et al (1998) point out that restricting membership in the FPC to one person per household, results in excluding women. Even where the one man \& one woman per household rule is adopted (as in AP), it still excludes a large number of disadvantaged women and in any case, formal membership means little unless the women are empowered to participate in decision making on the basis of ready access to information and alternative management options. In several villages women are unaware that they are members of a GB, let alone of the executive committee. Not only have women been excluded from community decision-making bodies by tradition, but JFM rules, in the name of protection, give further power to elite men to exclude poor forest dependent women from the forests. Hence, ensuring women's informed participation in the decision making process has to be the essential first step towards equal participation of women in community forestry management institutions (Kameshwari, 2002).

Empowerment of women in JFM has not effected in different regions of the State. Sunder et. al., (2001) study found that women were playing very little role in the management of JFM in Paderu of the Eastern Ghats of AP. NTFP conflicts are demoralising the people to give up joint management. The wage discrimination between the two adjacent JFM committees also 
discouraged the JFM activities. The wage rate here is as low as 20 and 25 to women and men respectively.

\section{Shortcomings of JFM in AP}

As per the State of Forest report, MoEF, GoI (1999), is concerned, an attempt to conserve the forests through the JFM has not produced the much-claimed positive impact in AP as a whole. Although a large number of the forest protection committees were established through the JFM, it couldn't control the deforestation. In fact, the same report further quotes that, before the formation of VSS / FPC in the State, the forest area was 23.02 per cent and it has declined to 16.08 percent In other words wherever VSS / FPC are very active deforestation rate is higher (Ravinder, 2003)

A major lacuna in the provision of VSS / FPC is that the involvement of the FD supersedes that of the villagers. The participatory role of the village people in the planning process of JFM has ignored by the FD officials. The micro-plan is framed in the forest office; rarely does it reach the villagers. People are rarely aware of the budgetary allocations and the budget plan for their village. Ideally the VSS / FPC should be in possession of a copy of the budget plan but that rarely happens. The second copy is with the Ranger, which is never shown.

Although JFM undoubtedly represents a change in the State's approach to forest management, there are still two sets of issues that need to be addressed (Saigal et. al., 1996, Roy, 1992). The first set is conceptual. For instance, to what extent do communities have economic (as opposed to subsistence) rights to forest produce? The second set of issues relate to the practical problems of managing the JFM programme including the assigning of forest areas to communities, developing systems for conflict resolution, dealing with different administrative and forest boundaries, and increasing women's participation and their active role.

The grazing policy alleged to be drafted in the backdrop of Mr. Naidu's Statement that 'goats are enemy to environment and forests' on $1^{\text {st }}$ April 2001 in the Assembly, is seen as anti-poor, antilow caste, pro-land owning caste and anti-livestock in general and 'goats' in particular. The reintroduction of in-discriminatory grazing fee for the livestock (as high as 40 rupees per goat 
per annum), prohibition of grazing on the interior protected forests (forest land is categorised into two), creation of 'paddocks' for grazing and delegation of 'permission authority' to the VSS / FPC Chairmen in the VSS / FPC areas has given the impression that Government is acting hand in glove with the World Bank to benefit the local elites and MNCs from Australia and New Zealand to further their interests in Indian meat market with their 'boneless meat'. Moreover, holding goats and their herders solely responsible for the destruction and deforestation is hard to digest since time immemorial they had been living in harmony with the mother-nature, knowing well that forests are their source of survival and its conservation is their own survival (Ravinder, 2003).

The other aspects, which adversely affected the performance of JFM in some areas, are the supposed elections to ECs, which were to be held once every two years leading to undemocratic practices by the 'elites' among the members (Reddy et.al, 2000). Majority of the ordinary members are not aware of the funds being released to their VSS / FPC. In some of the VSS / FPC the poor participation and inactive indulgence is due to the membership of non-tribals like artisans. For, the success of JFM, the support of the other departments working for the development of 'tribals' and 'rural development' need to co-operate with this scheme but unfortunately response from these departments is lukewarm and non-coordinated one (JFM - A Critique, Study).

According to Gopal and Upadhyay (2001) the legal and policy frameworks need more clarity because the provisions of the Executive Order governing JFM often conflict with the Forest Conservation Act leading to set backs in the efforts of the poor to seek livelihoods from the forests they improve. Livelihoods of the poor in the rural areas largely depend upon food, fuel wood, fodder, small timber and non-plant extractions. Hence the policy makers are expected to consider paying attention to these five categories as a policy of management rather than seeing it as an obstacle (Gopal and Upadhyay 2001). It is even more when the tribals within the Scheduled areas are finding it difficult to compensate livelihood losses due to restriction on head loading and Podu. 
Baviskar (1998) stresses on the importance of understanding the sensitivity of the 'tribal community' before making the policies pertaining to ecology and equity in tribal societies and into their internal dynamics because it is they who play an important role in the affairs of forest management and hence more powers and decision-making role to JFM committees should be given as a step toward greater decentralisation and devolution, an issue frequently raised by both supporters and critics of JFM movement though in different contexts (Jodha, 2000). More explicit and equitable sharing mechanisms to ensure benefits of JFM to tribals, landless labourers (particularly women) who have been deprived of their traditional earning options following the introduction of JFM in many areas, promote workable means to empower women, e.g., by raising their number at all levels of forest service (Jodha, 2000). Thousands of women will need to be inducted into the Indian Forest Service and the state cadre. This phase presents an immense challenge for recruiting the training. Furthermore, the organizational environment of forest agencies should be reoriented to allow women to participate equally with their male counterparts. Working groups, diagnostic studies, new monitoring systems, and feedback loops that enable emerging experiences to be channelled into policy-making will transform these institutions, making them accountable to their staff and the public that they serve (Poffenberger and Betsy Mc Gean, 1996).

\section{Conflict and Contentious Issues Emerging out of JFM and Absence of Proper Resolving Mechanism}

The following section presents our field observations from the three districts of Vishakhapatnam, Cuddapah and Adilabad representing the three different regions of the State.

\section{Sharing of VSS harvest}

Our field study has also come across the problems of sharing the VSS / FPC harvest. Since most of the VSS / FPC villages are ready to harvest the poles for which they are entitled to get the shares but the forest officials are seen to be delaying the same for the reasons better known to them. This phenomenon is observed in all the three districts of Adilabad, Cuddapha and Vishakapatnam. 


\section{Species Selection}

The other commonly found problem between the VSS / FPC members and forest officials is with regard to species selection. If the members insisted on coffee plantation in Vishakapatnam the Cuddapaha VSS / FPC stressed on horticulture plantation, while Adilabad VSS / FPC inclined to show interest on both, but forest officials have shown little interest on the members choice.

\section{Podu the burning issue}

Podu is one of the most contentious issues for all the stakeholders. This practice is seen mostly in the Vishakapatnam region wherein, the tribals contention is that it is their only meaningful source of livelihood apart from forestry. So they slash and burn the forest on hillock and practice cultivation. However introduction of PFM has to maximum extent succeeded in arresting this practice. Since the land given for VSS / FPC was once the Podu land, where the people are now seeing useful trees growing on it. Thus affording more income to them through VSS / FPC forestry than what they used to get under the rainfed agriculture. However few families in the VSS / FPC villages are still practicing the same in spite of the tall claims made by the FD. Hence it could not be ruled out that Podu has completely stopped. It is still a thorn in the flesh of the policy makers.

\section{Gender and JFM}

Our study has also not found PFM to be of any help in bringing equality between the two genders rather it is seen in every region that women being discriminated upon in terms of wages payment for carrying out work under PFM programmes. The wages are found to be very low when compared to men though the GO has strict provision against any discrimination in this regard. This phenomenon is unfortunately uniform across all the three regions.

\section{Grazing}

Among the studied three regions of the State grazing is not a big problem in the district of Vishakapatnam where the people do not find it difficult to graze their cattle since here open and wasteland is in abundance. Whereas in the other two districts it is a problem particularly in Cuddapah where the conflicts between the VSS / FPC members within the village or with neighbouring villages often occur when the cattle trod into their VSS / FPC area or reserved 
forest. It is more problematic in this region because of the absence of enough fodder in the forest to meet the cattle's requirement with continued drought adding to the complexities.

\section{Demarcation of VSS / FPC Area}

The VSS / FPC area is demarcated by the forest officials. In all most all the studied districts at least one instance of conflict due to demarcation is seen. Actually this happens because of the inefficiency on part of the forest officials in locating the boundaries as planned in the micro plan. It becomes more serious issue when FD gives the degraded or other forest to a particular VSS / FPC encroaching into the traditional boundary of neighbouring villages forest. Thus creating disharmony between the neighbouring villages ultimately showing adverse effect on the performance of the JFM altogether.

\section{Conflicts within VSS / FPC}

The internal conflicts between the VSS / FPC members were mostly of individual and personal in nature everywhere. But in one village in Cuddapah district there existed severe differences between some forty households against 14 or so households on the issue of cutting forest for wood. Though the 14 households are the members of the VSS / FPC yet they indulge in cutting the wood from their own VSS / FPC and reserved forest on the pretext of sustaining their livelihood. Though the other household try to dissuade them from doing so but has so for not resulted in any positive way. Even the protest carried to the forest officials fell on the deaf ears.

\section{GCC and its Monopoly over Minor Forest Produce}

Girijan Co-operative Corporation is a Government agency established to safe guard the interest of the tribals against the exploitation from the private traders and contractors when the matter comes to purchasing of forest produce from the tribals. GCC regulates and fixes the rates for the forest produce and it is mandatory on part of the tribals to sell the identified items (25) to the GCC only. There are disgruntlements among the tribals in the Vishakapatnam with regard to rates because they feel that they would get more remunerative price if they sale the same commodity to the private traders. However there are mixed opinions regarding this issue in the other two districts. It is so because the rates fixed by the GCC at least gives the bargaining power to the tribals who sell their forest produce illegally to the private traders. Since the benchmark of 
the rates starts from the fixed rate of the GCC and it is quite natural that they do not get less than what the GCC has fixed certain rate to particular commodity. This opinion is quite even across the three districts.

\section{PESA and JFM Institution}

Panchayat Extension Act to the Schedule areas (PESA) is limited only to Vishakapatnam and Adilabad and not to Cuddapha of the studied three districts. The people in these two regions are not aware of their rights at all. Though they know some thing called "Grama Sabha" and few of them also participate in it. But very rarely one or two individuals from each village have come across during the study, who knew that Grama Sabha under PESA have more or equal powers than the Panchayats.

\section{Community Forest Management (CFM): The New Forest Policy of AP}

Community Forest Management (CFM) implemented through GO 13 of February 2002 is an approach aimed at upgrading the initiatives taken in the area of JFM to CFM. While JFM was more a partnership between the forest dependent communities and the GoAP, CFM is more of a democratic process through delegation of the decision making process aimed at decentralizing the entire process of planning and implementation with APFD and GoAP acting more as facilitators and providers of technical and infrastructure support. CFM is an approach for forest development through a democratised participatory approach and empowering forest dependent local communities. It balances the local needs with external and environmental needs through increased productivity of the forest resources, reduced dependence on forests through substitution of demand and alternate livelihood opportunities, up gradation of living standards and above all inculcating a sense of ownership and pride among the forest dependent communities engaged in CFM. Community and farm forestry programmes carry out the basic objectives by strengthening local leadership, promoting participatory approaches and testing new approaches to JFM.

The enabling issues like legal backing for CFM, relaxation under FCA for medicinal plants cultivation by VSS / FPC, liberalization of State monopoly of NTFP, conformity of Panchayat laws with CFM regulations, conflict resolution among stakeholders and traditional rights, 
consistency of micro-plans with working plans, etc, have received special attention to create an enabling environment for holistic and sustainable development of forests. Apart from the above, other enabling issues like poverty alleviation through skill up gradation and income generating activities, training and capacity building, empowerment of women and other vulnerable groups, NGO's participation, etc, are also focused substantially in this latest Policy.

\section{Conclusions and Suggestions}

JFM is a different concept from many earlier attempts to promote forestry needs of the people, simply because it builds from the roles played by both local forest users and the professionals employed by the State to act as custodians. The combined effort of community and Government is the ultimate solution under prevailing circumstances therefore the Government intervention is expected to address the equity and transparency aspects to strengthen the voice of the poor. In the same way, participation of the people will warrant a constant vigil against all odds to protect the forests, hence VSS / FPC should be viewed as an entity for an overall development of village resources and its people, and not merely an instrument of developing the degraded forests, more so when the forthcoming endeavour of graduation from JFM to CFM focussing on alleviating rural poverty. This would be carried out through improved forest management and community development through participation of the stakeholders in a democratic participatory approach and empowering forest dependent local communities are expected to improve the forest development.

For the success of any programme of this nature and magnitude needs, top-level commitment at both political and official levels and process transparency. Unless the commitment is extended beyond missionary zeal towards humane and social regard the results would be ineffective. In the same way transparency wins the confidence of the people targeted by the programme. At the same time not ignoring the potentiality of the involvement of NGOs, who could play a crucial role. Above all if the programme is tailored to local conditions, culture, institutional and geoclimate not throttling local creativity and innovation there will be no stopping. Though most of these aspects are addressed in the CFM initiative of AP, the effectiveness of the programme depends largely on the implementation. As observed in other development programmes in AP, the implementation could suffer due to the scaling of the programme. This issue was observed to 
be crucial for the success of JFM by many district forest officials. For, even in the case of CFM FD continues to be the main implementing agency. The human resources of the department are not enough to follow the intensive approach of sustainable community participation when the scale of the programme is large, especially in the districts with larger forest areas. In this context, it is necessary to consider NGOs and Panchayats as implementing agencies. There is also an urgent need to first resolve the contentious issues of forest dwellers land and forest rights, providing them with tenure security for devolved management of community forests based on enhancing both livelihood and ecological security. At the same time 'Conflicts Resolving Mechanism' need to be developed to cope with the newer conflicts emerging out of the implementation of the programme of this magnitude.

\section{References}

- A P Forest Department: (No date) 'An Experience of Success in Behroonguda VSS', (www.ap.nic/apforest/default.htm).

- Arnold, David: (1982) 'Rebellions Hill men: The Gudem Rampa Raisings - 1924' in Ranjit Guha (eds) Subalteren Studies I - Writings on South Asian History and Society, P. $88-142$.

- Baviskar, Amita: (1998) 'Tribal Communities and Conservation in India' in (Kothari, A et al) 'Communities and Conservation', Sage Publications India Pvt.Ltd., New Delhi.

- Biswas, Kallol, Dharudu Murali, Reddappa Reddy, K Govindappa: (1997) 'People and Forest; Mutual Survival - A Case Study on the VSS of Nainayana Cheruvu, Anantapur District', for the Department of Social Work, April, Sri Krishna Devaraya University, Ananatapur, Andhra Pradesh.

- Census of India: (2001) 'Provisional Population Total-Andhra Pradesh', Office of the Registrar General of India, 2 A, Mansingh Road, New Delhi, (http://www.censusindia.net/profiles/apd.html).

- D' Silva, Emmanuel and B. Nagnath: (2002) 'Behroonguda: 'A Rare Success story in joint forest management', February 9, Economic and Political Weekly.

- Economic Survey: (2002-03) ‘

- Gogia, S. P: (2002) 'Andhra Pradesh Forest Laws', Asia Law House, Hyderabad. 
- Gopal, K, S and Sanjay Upadhyay: (2001) 'A Report on - Livelihoods and Forest Management In Andhra Pradesh', September, Prepared for the Natural Resources Management Programme, Andhra Pradesh.

- Government of AP (GoAP): (1999) 'Facts and Figures', Forest Department, Hyderabad.

- Jodha, N S: (2000) 'Joint Forest Management of Forests: Small Gains', Economic and Political Weekly, December 9, Pp.4396-4399.

- Joint Forest Management - A Critique: (No date) 'Based on People's Perspectives, A Study on the Impact of Joint Forest Management Programme in North Coastal Andhra Pradesh' Commissioned by National Tree Grower's Cooperative, Anand, Conducted by Samata and ten local community-based organisations under a federation called Coastal Rural Youth Network (CRY-Net).

- Kameshwar Rao K, P.V.Prasad Rao, Md. Iqbal, K.V.Padmavati Devi, T.S.Ramakrishana, P.Ramesh: (1995-96) 'Community Forest Management and Joint Forest Management in the Eastern Ghats Andhra Pradesh', in N. H. Ravindranath, K.S. Murali and K.C. Malhotra (eds): 'Joint Forest Management and Community Forestry in India - an ecological and institutional assessment', Oxford and IBH Publishing Co. Pvt. Ltd, New Delhi, 2000.

- Kameshwari, V.L.V: (2002) 'Gendered Communication and Access to Social Space Issues in Forest Management', Economic and Political Weekly, February 23, Pp. 797800.

- Mallet, Amie: (No date) 'Does the Eastablishment of Joint Forest Management Facilitate the Rejuvenation of Degraded Forest Land': Are you Surprised, www.colby.edu/personal/thtieten/defor-ind..

- MoEF, GoI: (1999): 'State of Forest report', in D. Ravinder's 'Forest and Grazing Politics in Andhra Pradesh: Contestations from Civil Society'.

- Muralidharudu., Redappa Reddy and Govindappa: (1997) 'Community organisation An essential element for the success of JFM, a case study of Hottebetta VSS', April, Sponsored by District Forest Office Anantapur to the Department of Rural Development and Social Work, Sri Krishna Devaraya University, Anantapur, Andhra Pradesh. 
- National Remote Sensing Agency (NRSA): (1995) 'Report on Area Statistics of Land Use / Land Cover Generated using Remote Sensing Technique', Government of India, Hyderabad.

- Pathy, Jagannath: (No date) 'Scheduled Tribes and Broken Promises' In Ajit Bhattacharjee (eds) Social Justice and the Constitution, IIAS, Simla.

- Poffenberger, M and B Mc Gean (edt): (1996) 'Village Voices, Forest Choices: Joint Forest Management in India', Oxford University Press, Delhi,

- Rangachari, C. S, and S. D Mukherji: (2000) 'Old Roots, New Shoots: A Study of Joint Forest Management in Andhra Pradesh', Winrock International and Ford Foundation, India, New Delhi.

- Rao, P. Kamala Manohar and D. L. Prasad Rao: (1982) 'Tribal Movements in Andhra Pradesh' in K. S. Singh (eds) Tribal Movements in India, Manohar, New Delhi.

- Rao, R. K: (No date) 'Tribal Land Problems and JFM', Hyderabad, The Hindu.

- Ravinder, D: (2003) 'Forest and Grazing Policies in Andhra Pradesh-Contestations from Civil Society', Unpublished Seminar Paper, CESS, Hyderabad.

- Reddy, Redappa. V., G. Sreedhar, K.Bhaskar, C.Sudhakar, K.Govindappa and M. Muninarayanappa: (2000) 'Impact Assessment Study of Joint Forest Management in Ananatapur District', March, for the Department of Rural Development and Social Work, Sri Krishnadevaraya University, Anantapur.

- Roy, Papia: (2001) 'Joint Forest Management - Vital issues', Kurukshetra, August, Pp.21-24.

- RUPFOR: (2002) (Resource Unit for Participatory Forestry) based on a recent JFM status paper by Madhya Pradesh Forest Department Official in 'Joint Forest Management - A Decade of Partnership', Joint Forest Management Monitoring Cell, MoEF, GoI, Winrock International India, New Delhi.

- Saigal, S., C. Agarwal and J. Y. Campbell: (1996) 'Sustaining Joint Forest management: The Role of Non-Timber Forest Products', mimeo, Society for the promotion of Wastelands Development, New Delhi.

- Sarin, M., L. Ray, M. S Raju, M. Chatterjee, N. Banerjee and S. Hiremath: (1988) 'Who Gains? And Who Loses? Gender and Equity Concerns in Joint Forest Management', Society for the Promotion of Wasteland Development, New Delhi. 
- Saxena, N. C: (2000) 'Forestry and Related Issues', Research Issues in Forestry in India, Indian Journal of Agriculture Economics, Vol. 55. No 3 July - September, Pp 359-383.

- Shiva (1998) in Kameshwari, V.L.V: (2002) 'Gendered Communication and Access to Social Space - Issues in Forest Management', Economic and Politica, weekly, February 23, Pp. 797-800.

- Sitaram, Rao: (1979) 'Introduction to Social Forestry', (Oxford and IBH Publishing Co., New Delhi.

- Sunder, N., Roger Jeffery, Neil Thin and others: (2001) 'Branching Out - Joint Forest Management', Oxford University Press, New Delhi.

- Venkatraman, A and Falconer: (No date) 'Rejuvenating India's Decimated Forests through joint actions: Lessons form Andhra Pradesh' Joint Forest Management Andhra Pradesh, (http://www.jfmindia.org). 